\title{
CHETODON SQUAMULOSUS.
}

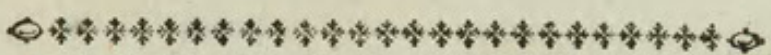

\section{CHARACTER GENERICUS.}

Dentes (plerifque) fetacei, flexiles, confertifimi, numerofiflimi.

Membrana brancbioftega radiis fex.

Corpus plerumque fafciatum. Pinna dorfi anique carnofa fquamofa.

CHARACTER SPECIFICUS, Eृ.

CHETODON viridi-aureus, fquamis fquamulofis.

ACARAUNA MAJOR, \&c.

$$
\text { Catefo. 2. p. 31.t. } 31 \text {. }
$$

Pifcem dépinximus non modica pulchritudine, juxta Americæe et infularum adjacentium litora copiofe fatis generatum, fquamis infigniter contectum quæ ipfæ minutius fquamatæ: quod vel folum fpeciem fatis denotet. Non raro errant auctores, qui nihil diftare opinantur hunc pifcem a Chatodonte trioftego Linnæi; ducitque eos in errorem quod falfo citatur in fyftematis Linnæani editione duodecima, indeque in alia multa opera irrepfit.

Accidere 
Accidere folet huic quod et aliis plerifque pifcibus, ut diverfis anni temporibus variet color; magis fcilicet minufve aureus, pinnis itidem magis minufve rubro-cæruleis. 



\section{DOUBLE-SCALED CHÆTODON.}

Q

\section{GENERIC CHARACTER.}

Teeth (in moft fpecies) fetaceous, fmall, very numerous.

- Body commonly fafciated tranfverfely. Dorfal and anal fins flemy and fcaly towards the bafe.

SPECIFIC CHARACTER, E̊C.

Gold-green CHETODON, with the fcales coated with fmaller ones.

The ANGEL-FISH.

This beautiful fifh is not uncommon about the coafts of America and the Weft Indian iflands. It is remarkable for the very fingular appearance of its fcales; which are each coated over with much fmaller ones; a particularity alone fufficient to diftinguifh this fpecies from almoft all others. It is often confounded with the Chrtodon trioftegus of Linnæus; owing to a miftaken quotation in the twelfth 
twelfth edition of the Syftema Naturæ of that author, and which has been carelefsly repeated by feveral others. In color, like moft fifhes, it varies at different feafons; being fometimes of a far richer and more golden tinge than at others; as well as with the blue and fcarlet of the fins either deeper or lighter according to circumftances. 


\section{$2 \mathrm{BHL}$ Biodiversity Heritage Library}

Shaw, George. 1797. "The Double-Scaled Chætodon, Chætodon squamulosus [PI. 275]." The Naturalist's Miscellany 8(XC), https://doi.org/10.5962/p.310818.

View This Item Online: https://www.biodiversitylibrary.org/item/276320

DOI: https://doi.org/10.5962/p.310818

Permalink: https://www.biodiversitylibrary.org/partpdf/310818

\section{Holding Institution}

Museums Victoria

\section{Sponsored by}

Atlas of Living Australia

\section{Copyright \& Reuse}

Copyright Status: Public domain. The BHL considers that this work is no longer under copyright protection.

This document was created from content at the Biodiversity Heritage Library, the world's largest open access digital library for biodiversity literature and archives. Visit BHL at https://www.biodiversitylibrary.org. 